Article

\title{
Examination of Teacher Candidates' Lifelong Learning Competence and Basic Motivation Resources as Parts of Sustainability
}

\author{
Gökhan Ilgaz ${ }^{1, *}$ and Menekşe Eskici ${ }^{2, *}$ \\ 1 Educational Science Department, Trakya University, Edirne 22000, Turkey \\ 2 Educational Science Department, Kurklareli University, Kırklareli 39000, Turkey \\ * Correspondence: gokhani@trakya.edu.tr (G.I.); menekeskici@hotmail.com (M.E.)
}

Received: 27 July 2018; Accepted: 14 December 2018; Published: 20 December 2018

check for updates

\begin{abstract}
The purpose of this research is to determine the level of teacher candidates' lifelong learning competence and basic motivation resources and to examine the lifelong learning competence and basic motivation of teacher candidates in terms of some variables (gender and to be a university student or not). For this purpose, a quantitative study was designed. The research was conducted with 382 teacher candidates being educated in the pedagogical formation program at Trakya University. In this research, "Key Competences for Lifelong Learning Scale" and "Basic Motivation Resources Scale" were used as tools for measurement. As a result of the analyses, it was determined that the basic motivation resources of teacher candidates in all of the dimensions of the scale and lifelong learning competence of teacher candidates except from "communicative competence at a foreign language/s" sub-dimension of the scale are above average. In terms of gender variables, significant difference was found in the "communicative competence at a foreign language/s" sub-dimension of "Key Competences for Lifelong Learning Scale" in favor of male teacher candidates and, on the other hand, significant differences were found in the "the competence of learning to learn" and "the competence of cultural awareness and expression" sub-dimension of "Key Competences for Lifelong Learning Scale" in favor of female teacher candidates.
\end{abstract}

Keywords: lifelong learning competence; basic motivation resources; sustainability; teacher candidates

\section{Introduction}

Human beings come into the world equipped with only a few reflexes, such as sucking and grabbing, but they need much more to survive. For this reason, their brains, which are hungry for learning, have helped to learn many actions from birth to death [1]. As a matter of fact, Duman [2] notes that learning is among the basic needs of humans. Billett [3] also notes that learning is a reality for humanity. Even though there are some differences between periods [4], humans need constant learning to adapt to the changing world and gain the necessary ills in all periods of their life [5]. In such a process, the individuals' learning struggle should be maintained lifelong, in other words, it should be sustainable [6]. Easy-to-access open sources pave the way for lifelong learning and supports the continuity of learning through sustainability [7]. In this context, Gülmez, Titrek, and Özkorkmaz [8] underline that formal education is not sufficient to obtain the ability, skill and knowledge which are necessary for individuals to cope with situations being encountered in their life, hence, informal education has a greater share in an individuals' life.

Development continues from the beginning to the end of life. Particularly cognitive development is actualized through learning $[9,10]$. The idea about a lifelong, conscious, and continuous learning process aiming at meeting the needs of both the individual and the concerned community [11,12] led 
to the emergence of the lifelong learning concept involving various activities [13] which is actualized for learning, continuing from birth to death. In this context, Knowles, who are shown as the pioneers of the lifelong learning concept, made the lifelong learning term widely used in education by stating that lifelong learning is the organizational principle of the whole education process [14].

The lifelong learning concept [15], which is used to describe the activities that people perform throughout their lives in order to develop their knowledge, skills, and competencies in a given area due to personal, social, or employment-related reasons, is seen as a process starting in the beginning of the pre-school and continuing throughout the compulsory education and teaching periods [16]. From this point of view, lifelong learning, which is seen as a continuous process [17], can be described as a set of learning activities aimed at improving the knowledge, skills, and competence of an individual [18]. Indeed, as pointed out by Kulich [19], the lifelong learning which can also be defined as giving education to the individuals throughout their lives, precisely means that education exists within all phases of the life cycle, in other words, throughout one's whole life [15].

The content of the concept of lifelong learning leads to the actualization of learning as a sustainable process, since learning never stops for humans, according to lifelong learning. The development of new ideas is indicated by Dash and Mohan [20]. Catching this development makes continuous learning to be essential, namely it obliges the individual to learn throughout life. Ryan and Deci [21] report that the individual should maintain lifelong learning with inner motivation, not pressure or award for sustainable lifelong learning. It is also stated by Hargreaves and Fink [6] that education has an important place for the renewal of human beings and that the most important difference distinguishing the living beings from non-living beings is the self-sustaining through renewal.

The increase in the production in all areas led to the consumption equally as well. As a reaction to this situation, the concept of sustainability emerged. Learning, which is the most basic need of individuals, has also been influenced by this concept. The individual learns throughout his/her life to achieve rapidly generated knowledge, and adapt to change. Gaymer [22] who stated that demands for lifelong learning in the 21st century have stemmed from a multitude of factors, such as increased knowledge, access to distorted and rapid technological changes, increasing global interactions, industry changes and skill requirements, some important features of lifelong learning in terms of duration, student-centered perspective, multi-level, and multi-subject learning and open access. Short-term goals, endless trials, and rapid political gains harm learning capacity of all students and the sustainability of education. On the other hand, countries that want to have an information economy increase day by day. However, the information economies are the learning communities. In such societies, the culture of economic success and continuous innovation can only be actualized by providing employees to devote themselves and each other to learning through their working lives [23].

Laal [15], who states that lifelong learning has the benefits of being able to cope with a rapidly changing world, having more salaries by offering more business opportunities, and enrichment of life, reports that lifelong learning is a strategy creating opportunity for making people to learn throughout their life. In this respect, it is seen that having superiority in every job depends on being a lifelong learner individual [24]. However, as pointed out by Akbaba [25], that the learner individual finds the learning activities meaningful and valuable and learning motivation which enables individual to benefit from them, are of great importance. As a matter of fact, educational psychologists recognized the importance of motivation to support student learning long time ago [26].

Motivation is seen as a driving force to stimulate, guide the individual and maintain his/her behavior in order to achieve the desired behavior [27]. Different approaches have been developed on the motivation [28] which means the underlying causes of behavior [29] and which is a force within the human that enables him/her to engage in positive or negative actions, reach certain needs and, thus, make him/her to be satisfied. Behavioral approaches among these approaches address motivation as an external process by explaining it with rewards and stimuli. Ryan and Deci [21] describe the external motivation as the impulses of individuals to exert their behaviors depending on external factors. According to the theory of cognitive motivation, individuals develop behaviors in accordance with the 
way they assess these external influences rather than only by them. Cognitive motivation process is intrinsic, and it is related to concepts such as curiosity, desire for learning and interest. In addition, intrinsic motivation is a very important mechanism for open-ended cognitive development, as pointed out by Oudeyer and Kaplan [30], because it is the driving force of spontaneous exploration and curiosity. Woolfolk [31] describes the main difference between these two motivations as the reason of the individual for the action. That is, it stems from the fact that causality focus of behavior is internal and external.

Explaining the behavior of a human who is a highly complex entity by depending on a single cause is not possible. In this respect, a number of theories and models regarding the motivation of people have been developed [32,33]. It can be said that the motivation concerning the learning of an individual is also influential on the quality of learning. Even if individuals have high-level learning skills, they will not be able to make sufficient efforts to achieve their goals as long as their motivation is low [34]. In this context, Ryan and Deci [21] define the sources of motivation as "three types of motivation, internal motivation, external motivation and being non-motivated, based on the theory of "autonomy". Thanks to the internal motivation, defined as the making of an activity for internal satisfaction, a person acts because he/she likes to, not because of pressures or awards. External motivation is a structure that is possessed when an activity is performed in order to obtain some separable outcomes [21,30,35].

Individuals have innate internal stimulation and desire for learning according to the theory of autonomy [36]. As pointed out by Emily [26], even though motivation tendency decreases in general when children start the school, they seem to be at high levels of intrinsic motivation. Reasons for the motivation of individuals to learn can be grouped positively as the achievement of success, and can be grouped negatively as getting rid of punishment [25]. Motivation can be manipulated through some teaching practices, and both its positive and negative effects can be observed [28]. Motivation is grouped both internally and externally $[37,38]$. The individual gains control over with in internal motivation and external factors gain control with external motivation [39]. Mottaz [40] stated that internal motivation is a very important factor in realizing the individual's desires. In addition, social goals and self-reinforcement system are also effective on the development of motivation $[39,41]$.

Individuals must be in education process which is independent, active and lifelong in the information society. Since the pace of change makes learned knowledge and skills to be invalid or ineffective in a short time. Thus, individuals living in an information society will continue to learn through life by gaining the ability of learning to learn. Lifelong learning is a process that is actualized as official/formal (teaching provided by an educational institution) and unofficial/informal (learning that takes place in daily activities related to work, family, or leisure time, and not provided by an educational institution) [42]. Lifelong learning is an ongoing need to be maintained, namely, a sustainable process. The motivation level of individuals should be high so that learning can be a sustainable process. Since learning is considered as a necessity, being motivated for learning in required areas is also inevitable.

As teacher candidates are the teachers of the future, they have an important place in the education process. It is considered that determining the lifelong learning competence and the main motivational sources of teacher candidates is necessary for organizing teacher education. The evaluation of teachers is inevitable for the sustainability of teacher education [43]. The lifelong learning competencies of teacher candidates are decisive for their successful performance in the cultural development of society [44]. It is considered that determining the specific characteristics of teacher candidates will form the basis of teacher training programs. When the literature is examined, there are studies $[42,44]$ showing that lifelong learning competencies do not change according to the gender of the teacher candidates. Additionally, when the literature is examined, there are studies [45-47] showing that lifelong learning competence of teacher candidates are in favor of the female. In contrast, in this case, there are studies $[48,49]$ showing that lifelong learning competence of teacher candidates are in favor of the male. When the literature is examined, it is seen that the lifelong learning competence of teacher 
candidates show different results according to the gender variable. Therefore, it can be stated that the lifelong competence of teacher candidates should be examined according to the gender variable.

For this reason, importance of both the lifelong learning competence of teachers who have a great place in the life of students and their basic motivation sources come to the forefront in the education process. By looking at this importance, it is aimed to determine the lifelong learning competence of the teacher candidates and their basic motivation sources in this research. Within the scope of this purpose, answers were sought for the following questions:

1. What are the levels of teacher candidates' lifelong learning competence and basic motivation resources?

2. What are teacher candidates' lifelong learning competence and basic motivation resources in terms of gender?

3. What are teacher candidates' lifelong learning competence and basic motivation resources in terms of continuing university education?

4. What are the relations of teacher candidates' lifelong learning competence and basic motivation resources?

\section{Materials and Methods}

The study was a quantitative research and a survey was applied in this research. In this study the relationship between teacher candidates' own perceptions of competences towards lifelong learning and basic motivation sources were examined. Instead of teacher candidates' real cognitive structures, views, and skills related to lifelong learning was used.

\subsection{Population}

The population of the study consists of teacher candidates who were enrolled in the Pedagogical Formation Program at Trakya University in the 2017-2018 academic year. We did not apply any sampling method. We wanted to reach all teacher candidates. Thus, the research was conducted with 382 (276 females and 106 males) teacher candidates. The participants were presented in Tables 1 and 2.

Table 1. The education fields of participants.

\begin{tabular}{clc}
\hline Departments & $\mathbf{f}$ & $\mathbf{\%}$ \\
\hline Religion & 12 & 3.14 \\
Literature & 65 & 17.01 \\
Philosophy & 104 & 27.23 \\
Group & & 7.59 \\
Fine Arts & 29 & 9.95 \\
Sports & 38 & 22.51 \\
History & 86 & 9.69 \\
Trade & 37 & 2.88 \\
Tourism & 11 & 100.00 \\
Total & 382 & \\
\hline
\end{tabular}

Table 2. The gender status of participants.

\begin{tabular}{|c|c|c|c|c|}
\hline & & \multicolumn{2}{|c|}{ Student } & \multirow[b]{2}{*}{ Total } \\
\hline & & $\begin{array}{l}\text { I am a University } \\
\text { Student Right Now }\end{array}$ & $\begin{array}{l}\text { I am not a University } \\
\text { Student Right Now }\end{array}$ & \\
\hline \multirow{2}{*}{ Gender } & Female & 66 & 210 & 276 \\
\hline & Male & 20 & 86 & 106 \\
\hline \multicolumn{2}{|c|}{ Total } & 86 & 296 & 382 \\
\hline
\end{tabular}


Teacher candidates in this study are involved in a common education program. Teacher training is done basically two ways in Turkey. The first of these ways is carried out through the Faculty of Education within the formal education system. All the branches, except the technical ones, are studied in the faculties. Since 2010, however, a limited number of teacher candidates have been recruited to the education faculties. The source of the high school teacher training is the Pedagogical Formation Certificate program, which is a common area of education. The prerequisites for applying to this program is to complete a bachelor's degree or to be a senior undergraduate student. The extra rules for application depend on universities. The reason why this group is included in the study is that they take part in business life in different sectors. Individuals in active business life are considered to have more opportunities and exigence to develop and use lifelong learning skills. On the other hand, these groups will work mainly with high school students. In other words, they will teach the closest students to enter the business world. It is important to determine the participants' beliefs and life motivations about lifelong learning competencies because they have the potential to influence students and, thus, contribute to the growth of learning societies.

\subsection{Data Collection Tools}

In this research, "Key Competences for Lifelong Learning Scale" developed by Şahin, Akbaşl1, and Yanpar Yelken [50] and "Basic Motivation Resources Scale" developed by Antalyalı and Bolat [51] were used as tools for measurement.

Key Competences for Lifelong Learning Scale was developed with 445 prospective teachers. The scale has 23 items and eight dimensions which are communicative competence at native language (4 items), communicative competence at a foreign language/s (four items), mathematics-based competence at science and technology (three items), digital competence (two items), the competence of learning to learn (two items), the competence of social citizenship awareness (three items), the competence of the sense of initiative and entrepreneurship (four items), and the competence of cultural awareness and expression (one item). The scale items were designed as a five-point Likert type. For whole scale, the Cronbach alpha reliability value is 0.75 .

The second scale was the Basic Motivation Resources Scale. The scale has 24 items and four dimensions which are the need for achievement (six items), the need for affiliation (six items), the need for power (six items), and the need for cognition (six items). The scale items were designed as a seven-point Likert type. The scale was developed in two phases. In the first phase, data were collected from 1337 undergraduate students in 12 rounds over a period of eight months and the scale was developed by improving the scale in each round. In the second phase, the scale was applied to 356 undergraduate students and 286 white-collar employees working in a holding company. Based on the data obtained, exploratory and confirmatory factor analysis were performed. As a result of the analysis, 24 items and four-dimensional, each consisting of six items, scales were reached. For the students and the employees of the sub-dimensions of the scale, the Cronbach alpha reliability values are presented in Table 3.

Table 3. Cronbach alpha reliability values of the of Basic Motivation Resources Scale dimensions.

\begin{tabular}{ccc}
\hline Dimensions & Students & Employees \\
\hline The Need for Achievement & 0.78 & 0.74 \\
The Need for Affiliation & 0.73 & 0.74 \\
The Need for Power & 0.79 & 0.80 \\
The Need for Cognition & 0.82 & 0.82 \\
\hline
\end{tabular}

The interests, attitudes and behaviors of males and females differ from each other [51]. These differences can affect learning and teaching behaviors. For example, Yaman and Yazar [52] and Kirby, Knapper, Lamon, and Egnatoff [53] found no significant difference in terms of lifelong learning, whereas the study by Gencel [45] was in favor of women in communication skills in foreign languages; 
in the field of mathematics, science, and technology, only a significant difference was determined in favor of men. On the other hand, there are studies [54,55] showing that female teachers participate more in in-service trainings as lifelong learning. There are studies showing that students of teachers who participated in in-service trainings achieve more success [56,57]. From this point of view, it can be stated that evaluating the lifelong learning trends of the prospective teachers in terms of gender will determine the participation profile of the in-service programs in the future. However, it is the motivation of the building that motivates people. Motivation for learning is one of the basic elements. The distribution of motivation by gender will provide information to the education policies in guiding in-service training.

\subsection{Analyzing Data}

There are no missing data in this study. If there had been a missing data in the study, the data would have been solved by using list wise deletion [58,59]. For the analysis of the data, the mean and standard deviation were calculated. The average of the sub-dimensions was divided by the number of items in order to find the average of the sub-dimensions of the scales. The normality of the distributions was checked to determine whether or not the difference between the averages in terms of gender and to be a university student variables were significant. For the assumption of normality, the values of skewness and kurtosis are accepted to be between \pm 1 [60]. The $t$-test was used for situations where the data were normally distributed, and Mann-Whitney $U$ test was used when the data were not distributed normally. The correlation $r$ value was calculated for the effect size of significant outcomes. In the interpretation of this value, it was considered as 0.10 small, 0.30 medium, and 0.50 large [61]. The Pearson correlation coefficient was calculated when the relationship between variables was assumed to be normal, and the Spearman correlation coefficient was calculated when the relationship between variables was assumed to be abnormal.

In cases of meaningful relationship, Fisher $r$-to-z transformation test was used to calculate whether or not there was a significant difference between the correlations [62]. This calculation is done in three steps [63]. First, the coefficient $r$ is converted to $z$ distribution by $z=0.5[\ln (1+r) /(1-r)]$. In the formulas $r$ is the correlation value and $\ln$ is natural logarithm. In the second step, the following formula is applied in order to determine the difference of the calculated values for both correlation values, $n$ is the number of participants of two different groups:

$$
z^{\prime}=\frac{z_{1}-z_{2}}{\sqrt{\frac{1}{n_{1}-3}+\frac{1}{n_{2}-3}}}
$$

In the final step, it is concluded that there is no significant difference between the coefficients, if the value obtained is less than 1.96 at a 0.05 significance level.

\section{Findings}

The findings obtained in the research are presented in the tables below.

\subsection{Teacher Candidates' Lifelong Learning Competence and Basic Motivation Resources Levels}

Mean and standard deviation values of teacher candidates' lifelong learning competence and basic motivation resources are given in Table 4 .

Table 4. Mean and standard deviation values of teacher candidates' lifelong learning competence and basic motivation resources.

\begin{tabular}{|c|c|c|c|c|c|c|}
\hline \multicolumn{7}{|c|}{ Descriptive Statistics } \\
\hline & & Minimum & Maximum & Mean & Std. Deviation & Mean/Item Number \\
\hline \multirow{3}{*}{ Basic Motivation Resources } & The Need FOR Achievement & 11.00 & 42.00 & 30.12 & 7.24 & 5.02 \\
\hline & The Need For Power & 6.00 & 42.00 & 26.74 & 7.79 & 4.46 \\
\hline & The Need For Cognition & 15.00 & 42.00 & 32.32 & 5.68 & 5.39 \\
\hline
\end{tabular}


Table 4. Cont.

\begin{tabular}{|c|c|c|c|c|c|c|}
\hline \multicolumn{7}{|c|}{ Descriptive Statistics } \\
\hline & & Minimum & Maximum & Mean & Std. Deviation & Mean/Item Number \\
\hline \multirow{5}{*}{ Lifelong Learning Competence } & $\begin{array}{c}\text { Communicative competence } \\
\text { at native language }\end{array}$ & 9.00 & 22.00 & 17.85 & 2.40 & 4.46 \\
\hline & $\begin{array}{l}\text { Mathematics-based } \\
\text { competence at science } \\
\text { and'technology }\end{array}$ & 3.00 & 15.00 & 9.45 & 2.51 & 3.15 \\
\hline & $\begin{array}{l}\text { The competence of } \\
\text { learning to learn }\end{array}$ & 3.00 & 10.00 & 7.99 & 1.65 & 3.99 \\
\hline & $\begin{array}{l}\text { The competence of social } \\
\text { citizenship awareness }\end{array}$ & 6.00 & 15.00 & 12.17 & 2.31 & 4.06 \\
\hline & $\begin{array}{c}\text { The competence of the sense } \\
\text { of initiative and } \\
\text { entrepreneurship }\end{array}$ & 7.00 & 20.00 & 16.13 & 2.89 & 4.03 \\
\hline
\end{tabular}

According to Table 4 basic motivation resources of teacher candidates have higher scores than average. Intercalary lifelong learning competence of teacher candidates except from the "communicative competence at a foreign language/s" sub-dimension of the scale is above average.

\subsection{Teacher Candidates' Lifelong Learning Competence and Basic Motivation Resources in Terms of Gender}

The results of the $t$-test and Mann-Whitney $U$ test, which were made in order to determine whether or not there is a significant difference between teacher candidates' lifelong learning competence and basic motivation resources in terms of gender, are presented in Tables 5 and 6.

Table 5. Teacher candidates' lifelong learning competence and basic motivation resources in terms of gender for normal distribution.

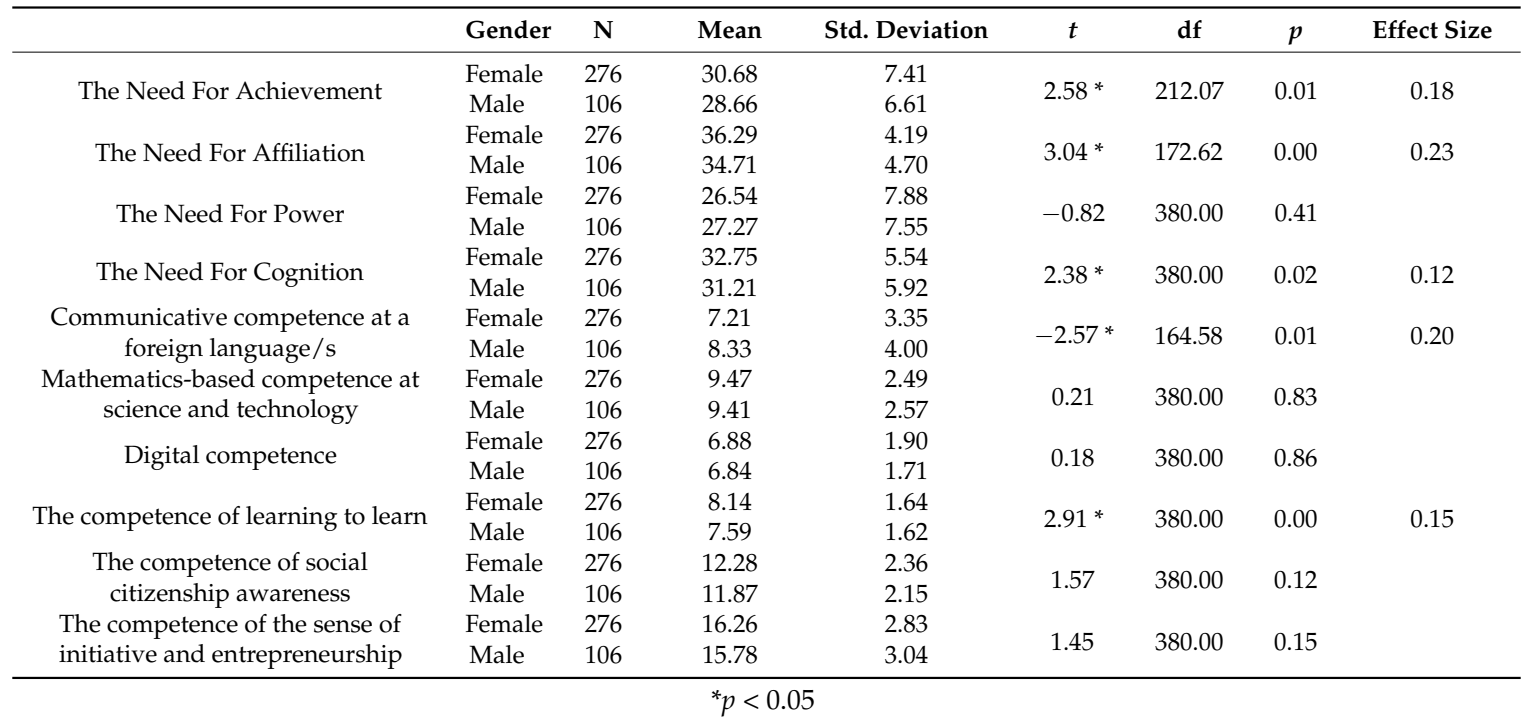

As seen in Table 5 considering teacher candidates' gender, significant difference was found in the "communicative competence at a foreign language/s" sub-dimension of "Key Competences for Lifelong Learning Scale" in favor of male teacher candidates. On the other hand, significant difference was found in the "the competence of learning to learn" and "the competence of cultural awareness and expression" and "communicative competence at native language" sub-dimensions of "Key Competences for Lifelong Learning Scale" in favor of female teacher candidates. In addition, significant difference was found in the "the need for achievement", "the need for affiliation", "and the need for cognition" sub-dimensions of "Basic Motivation Resources Scale" in favor of female teacher 
candidates. Additionally, there is no significant difference between the other sub-dimensions of the scales and the gender of the teacher candidates.

Table 6. Teacher candidates' lifelong learning competence and basic motivation resources in terms of gender for abnormal distribution.

\begin{tabular}{ccccccc}
\hline & Gender & N & Mean Rank & Sum of Ranks & U & Effect Size \\
\hline Communicative competence at & Female & 276 & 200.90 & $55,447.50$ & \multirow{2}{*}{$12,034.500 *$} & 0.14 \\
native language & Male & 106 & 167.03 & $17,705.50$ & & \multirow{2}{*}{0.11} \\
The competence of cultural & Female & 276 & 199.09 & $5,494,750$ & $12,534.500 *$ & \\
awareness and expression & Male & 106 & 171.75 & $18,205.50$ & &
\end{tabular}

\subsection{Teacher Candidates' Lifelong Learning Competence and Basic Motivation Resources in Terms of Continuing University Education}

The results of $t$-test and Mann-Whitney $U$ test made in order to determine whether there is a significant difference between teacher candidates' lifelong learning competence and basic motivation resources in terms of continuing university education are presented in Tables 7 and 8.

Table 7. Teacher candidates' lifelong learning competence and basic motivation resources in terms of continuing university education normal distribution.

\begin{tabular}{|c|c|c|c|c|c|c|c|c|}
\hline & & $\mathbf{N}$ & Mean & Std. Deviation & $t$ & df & $p$ & Effect Size \\
\hline \multirow{2}{*}{ The Need For Achievement } & $\begin{array}{l}\text { I am a university } \\
\text { student right now }\end{array}$ & 86 & 31.35 & 7.35 & \multirow[t]{2}{*}{1.80} & \multirow[t]{2}{*}{380} & \multirow[t]{2}{*}{0.07} & \multirow[t]{2}{*}{0.09} \\
\hline & $\begin{array}{l}\text { I am not a university } \\
\text { student right now }\end{array}$ & 296 & 29.76 & 7.19 & & & & \\
\hline \multirow{2}{*}{ The Need For Affiliation } & $\begin{array}{l}\text { I am a university } \\
\text { student right now }\end{array}$ & 86 & 36.10 & 4.51 & \multirow[t]{2}{*}{0.60} & \multirow[t]{2}{*}{380} & \multirow[t]{2}{*}{0.55} & \\
\hline & $\begin{array}{l}\text { I am not a university } \\
\text { student right now }\end{array}$ & 296 & 35.78 & 4.36 & & & & \\
\hline \multirow{2}{*}{ The Need For Power } & $\begin{array}{l}\text { I am a university } \\
\text { student right now }\end{array}$ & 86 & 27.47 & 8.40 & \multirow[t]{2}{*}{0.98} & \multirow[t]{2}{*}{380} & \multirow[t]{2}{*}{0.33} & \\
\hline & $\begin{array}{l}\text { I am not a university } \\
\text { student right now }\end{array}$ & 296 & 26.53 & 7.60 & & & & \\
\hline \multirow[t]{2}{*}{ The Need For Cognition } & $\begin{array}{l}\text { I am a university } \\
\text { student right now }\end{array}$ & 86 & 33.15 & 5.24 & \multirow[t]{2}{*}{1.54} & \multirow[t]{2}{*}{380} & \multirow[t]{2}{*}{0.12} & \\
\hline & $\begin{array}{l}\text { I am not a university } \\
\text { student right now }\end{array}$ & 296 & 32.08 & 5.79 & & & & \\
\hline \multirow{2}{*}{$\begin{array}{l}\text { Communicative competence at } \\
\text { a foreign language/s }\end{array}$} & $\begin{array}{l}\text { I am a university } \\
\text { student right now }\end{array}$ & 86 & 7.98 & 4.31 & \multirow[t]{2}{*}{1.18} & \multirow[t]{2}{*}{115.87} & \multirow[t]{2}{*}{0.24} & \\
\hline & $\begin{array}{l}\text { I am not a university } \\
\text { student right now }\end{array}$ & 296 & 7.39 & 3.32 & & & & \\
\hline \multirow{2}{*}{$\begin{array}{l}\text { Mathematics-based competence } \\
\text { at science and technology }\end{array}$} & $\begin{array}{l}\text { I am a university } \\
\text { student right now }\end{array}$ & 86 & 10.19 & 2.41 & \multirow[t]{2}{*}{3.12} & \multirow[t]{2}{*}{380} & \multirow[t]{2}{*}{0.00} & \multirow[t]{2}{*}{0.16} \\
\hline & $\begin{array}{l}\text { I am not a university } \\
\text { student right now }\end{array}$ & 296 & 9.24 & 2.50 & & & & \\
\hline \multirow{2}{*}{$\begin{array}{c}\text { The competence of learning } \\
\text { to learn }\end{array}$} & $\begin{array}{l}\text { I am a university } \\
\text { student right now }\end{array}$ & 86 & 8.40 & 1.62 & \multirow[t]{2}{*}{2.63} & \multirow[t]{2}{*}{380} & \multirow[t]{2}{*}{0.01} & \multirow[t]{2}{*}{0.13} \\
\hline & $\begin{array}{l}\text { I am not a university } \\
\text { student right now }\end{array}$ & 296 & 7.87 & 1.64 & & & & \\
\hline \multirow{2}{*}{$\begin{array}{l}\text { The competence of social } \\
\text { citizenship awareness }\end{array}$} & $\begin{array}{l}\text { I am a university } \\
\text { student right now }\end{array}$ & 86 & 12.59 & 2.33 & \multirow[t]{2}{*}{1.95} & \multirow[t]{2}{*}{380} & 0.05 & \\
\hline & $\begin{array}{l}\text { I am not a university } \\
\text { student right now }\end{array}$ & 296 & 12.04 & 2.29 & & & & \\
\hline The competence of the sense of & $\begin{array}{l}\text { I am a university } \\
\text { student right now }\end{array}$ & 86 & 16.74 & 2.98 & 2.25 & 380 & 0.02 & 0.12 \\
\hline initiative and entrepreneurship & $\begin{array}{l}\text { I am not a university } \\
\text { student right now }\end{array}$ & 296 & 15.95 & 2.85 & & & & \\
\hline The competence of cultural & $\begin{array}{l}\text { I am a university } \\
\text { student right now }\end{array}$ & 86 & 3.77 & 1.20 & -0.44 & 380 & 0.66 & \\
\hline awareness and expression & $\begin{array}{l}\text { I am not a university } \\
\text { student right now }\end{array}$ & 296 & 3.83 & 1.10 & & & & \\
\hline
\end{tabular}


Table 8. Teacher candidates' lifelong learning competence and basic motivation resources in terms of continuing university education non-normal distribution.

\begin{tabular}{|c|c|c|c|c|c|c|}
\hline & Student & $\mathbf{N}$ & Mean Rank & Sum of Ranks & $\mathrm{U}$ & Effect Size \\
\hline \multirow{2}{*}{$\begin{array}{l}\text { Communicative competence } \\
\text { at native language }\end{array}$} & $\begin{array}{l}\text { I am a university student } \\
\text { right now }\end{array}$ & 86 & 222.33 & $19,120.00$ & \multirow[t]{2}{*}{$10,077^{*}$} & \multirow{4}{*}{0.15} \\
\hline & $\begin{array}{l}\text { I am not a university student } \\
\text { right now }\end{array}$ & 296 & 182.54 & $54,033.00$ & & \\
\hline \multirow[t]{2}{*}{ Digital competence } & $\begin{array}{c}\text { I am a university student } \\
\text { right now }\end{array}$ & 86 & 205.30 & $17,655.50$ & \multirow[t]{2}{*}{$11,541.5$} & \\
\hline & $\begin{array}{l}\text { I am not a university student } \\
\text { right now }\end{array}$ & 296 & 187.49 & $55,497.50$ & & \\
\hline
\end{tabular}

As seen Tables 7 and 8, a significant difference was found in "communicative competence at native language", "mathematics-based competence at science and technology", "the competence of learning to learn", and "the competence of the sense of initiative and entrepreneurship" sub-dimensions of the "Key Competences for Lifelong Learning Scale" in favor of teacher candidates continuing university education. In addition, significant difference was found in the "the need for achievement" sub-dimension of "Basic Motivation Resources Scale" in favor of teacher candidates continuing university education. Additionally, there is no significant difference between the other sub-dimensions of the scales and to be a university student or not.

\subsection{Relation of Teacher Candidates' Lifelong Learning Competence and Basic Motivation Resources}

The results of the correlation test made to determine the relationship of teacher candidates' lifelong learning competence and basic motivation resources are presented in Tables 9-11.

When Table 9 is examined it can be said that there is no relationship between the "communicative competence at a foreign language/s" sub-dimension of the "Key Competences for Lifelong Learning Scale" and other sub-dimensions of the scale.

Significant relation was found between the "Key Competences for Lifelong Learning Scale" and the "Basic Motivation Resources Scale" except for the relationship between the "mathematics-based competence at science and technology" sub-dimension of the "Key Competences for Lifelong Learning Scale" and "the need for affiliation" and "the need for power" sub-dimensions of the "Basic Motivation Resources Scale" as well except for the relationship between the "communicative competence at native language/s" sub-dimension of the "Key Competences for Lifelong Learning Scale" and "the need for power" sub-dimension of the "Basic Motivation Resources Scale".

When examined on a gender basis, there is a meaningful relationship between "the need for power" sub-dimension of the "Basic Motivation Resources Scale" with "communicative competence at native language/s" and "competence of cultural awareness and expression" sub-dimensions of the "Key Competences for Lifelong Learning Scale" in terms of male teacher candidates.

When examined in terms of female teacher candidates, there is a significant relationship between "the need for power" sub-dimension of "Basic Motivation Resources Scale" with "the competence of the sense of initiative and entrepreneurship" and "digital competence" sub-dimensions of the "Key Competences for Lifelong Learning Scale",

"The Need For Achievement" sub-dimension of the "Basic Motivation Resources Scale" with he "mathematics-based competence at science and technology" sub-dimension of the "Key Competences for Lifelong Learning Scale".

"The need for power", "the need for affiliation", and "the need for cognition" sub-dimensions of the "Basic Motivation Resources Scale" with the "digital competence" sub-dimension of the "Key Competences for Lifelong Learning Scale" and "the need for cognition" sub-dimension of the "Basic Motivation Resources Scale" with "communicative competence at a foreign language/s" and "mathematics-based competence at science and technology" sub-dimensions of the "Key Competences for Lifelong Learning Scale". 
Table 9. General relationship of teacher candidates' lifelong learning competence and basic motivation resources.

\begin{tabular}{|c|c|c|c|c|c|c|c|c|c|c|c|}
\hline & 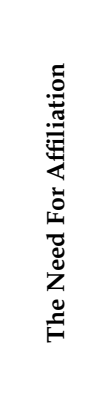 & 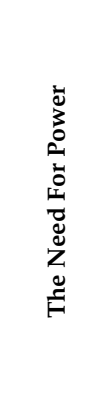 & 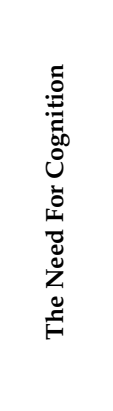 & 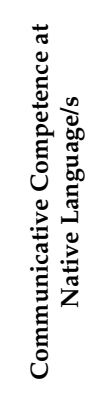 & 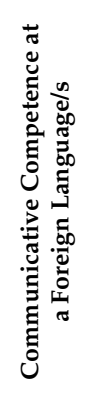 & 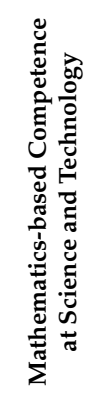 & 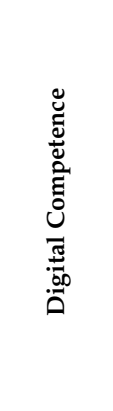 & 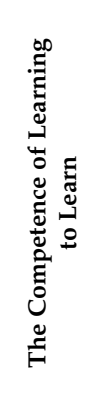 & 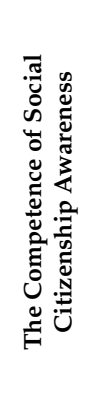 & 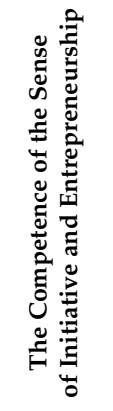 & 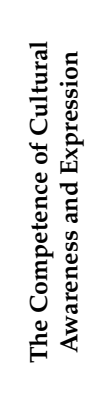 \\
\hline The Need For Achievement & $0.195^{* *}$ & 0.182 ** & $0.315^{* *}$ & $0.250^{* *}$ & 0.029 & $0.263^{* *}$ & $0.242 * *$ & $0.334^{* *}$ & $0.284^{* *}$ & $0.343^{* *}$ & $0.186^{* *}$ \\
\hline The Need For Affiliation & & 0.009 & $0.239^{* *}$ & $0.119^{*}$ & -0.07 & 0.05 & $0.124 *$ & $0.195^{* *}$ & $0.208 * *$ & $0.196 * *$ & $0.123 *$ \\
\hline The Need For Power & & & $0.219^{* *}$ & 0.08 & 0.086 & 0.074 & $0.199 * *$ & $0.106 *$ & $0.182 * *$ & $0.167^{* *}$ & $0.105 *$ \\
\hline The Need For Cognition & & & & $0.220 * *$ & 0.087 & $0.113 *$ & $0.207 * *$ & $0.243 * *$ & 0.288 ** & $0.261^{* *}$ & $0.251 * *$ \\
\hline Communicative competence at native language $/ \mathrm{s}$ & & & & & 0.046 & $0.185^{* *}$ & $0.237^{* *}$ & 0.339 ** & $0.399 * *$ & $0.431^{* *}$ & 0.204 ** \\
\hline Communicative competence at a foreign language/s & & & & & & 0.096 & $0.172 * *$ & 0.044 & 0.065 & 0.099 & $0.124 *$ \\
\hline Mathematics-based competence at science and technology & & & & & & & $0.405^{* *}$ & $0.407 * *$ & $0.317^{* *}$ & 0.383 ** & $0.119 *$ \\
\hline Digital competence & & & & & & & & $0.459 * *$ & $0.359 * *$ & $0.435^{* *}$ & $0.278^{* *}$ \\
\hline The competence of learning to learn & & & & & & & & & 0.566 ** & $0.594^{* *}$ & $0.305^{* *}$ \\
\hline The competence of social citizenship awareness & & & & & & & & & & $0.619^{* *}$ & $0.290 * *$ \\
\hline The competence of the sense of initiative and entrepreneurship & & & & & & & & & & & $0.428^{* *}$ \\
\hline
\end{tabular}

** Correlation is significant at the 0.01 level (2-tailed). ${ }^{*}$ Correlation is significant at the 0.05 level (two-tailed).

Table 10. Relationship of teacher candidates' lifelong learning competence and basic motivation resources based on gender.

\begin{tabular}{|c|c|c|c|c|c|c|c|c|c|c|c|c|c|}
\hline & & & 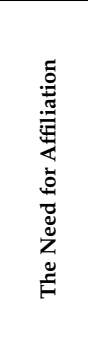 & 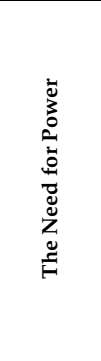 & 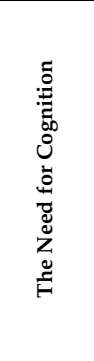 & 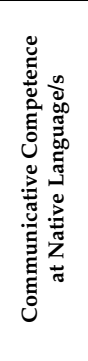 & 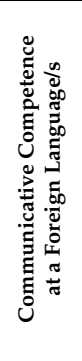 & 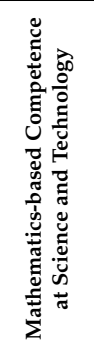 & 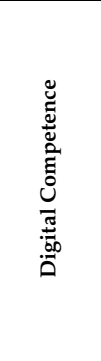 & 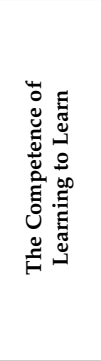 & 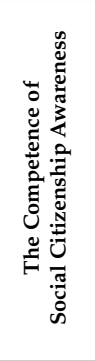 & 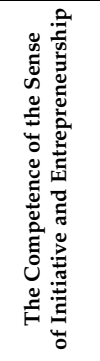 & 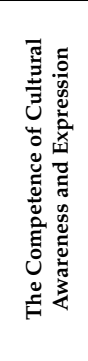 \\
\hline The Need For Achievement & Gender & $\begin{array}{l}\text { Female } \\
\text { Male } \\
\text { F }\end{array}$ & $\begin{array}{c}0.180 \text { ** } \\
0.178 \\
0.02\end{array}$ & $\begin{array}{c}0.174^{* *} \\
0.235 \text { * } \\
0.55\end{array}$ & $\begin{array}{c}0.304 \text { ** } \\
0.311 \text { ** } \\
0.07\end{array}$ & $\begin{array}{c}0.246 * * \\
0.234 * \\
0.11\end{array}$ & $\begin{array}{l}0.060 \\
0.017\end{array}$ & $\begin{array}{c}0.314 \text { ** } \\
0.123\end{array}$ & $\begin{array}{c}0.255^{* *} \\
0.205^{*} \\
0.46\end{array}$ & $\begin{array}{c}0.297 \text { ** } \\
0.396^{* *} \\
0.97\end{array}$ & $\begin{array}{l}0.259 \text { ** } \\
0.335 \text { ** } \\
0.72\end{array}$ & $\begin{array}{l}0.318^{* *} \\
0.397 \text { ** } \\
0.78\end{array}$ & $\begin{array}{c}0.143^{*} \\
0.263 \text { ** } \\
1.08\end{array}$ \\
\hline
\end{tabular}


Table 10. Cont.

\begin{tabular}{|c|c|c|c|c|c|c|c|c|c|c|c|c|c|}
\hline & & & 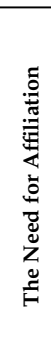 & 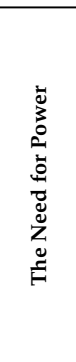 & 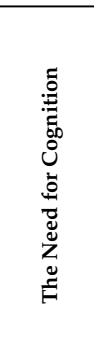 & 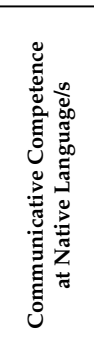 & 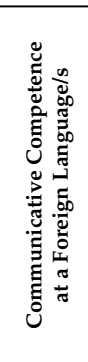 & 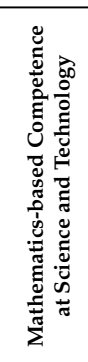 & 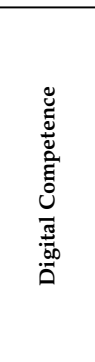 & 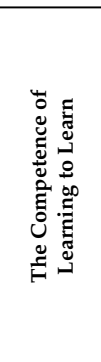 & 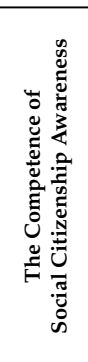 & 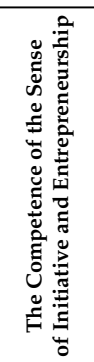 & 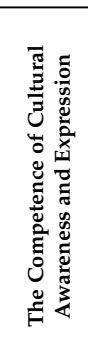 \\
\hline The Need For Affiliation & Gender & $\begin{array}{c}\text { Female } \\
\text { Male } \\
\mathrm{F}\end{array}$ & & $\begin{array}{l}0.009 \\
0.035\end{array}$ & $\begin{array}{l}0.208 \text { ** } \\
0.258 \text { ** } \\
0.46\end{array}$ & $\begin{array}{l}0.076 \\
0.133\end{array}$ & $\begin{array}{l}-0.050 \\
-0.043\end{array}$ & $\begin{array}{l}0.052 \\
0.043\end{array}$ & $\begin{array}{l}0.126^{*} \\
0.121\end{array}$ & $\begin{array}{c}0.128^{*} \\
0.288^{* *} \\
1.45\end{array}$ & $\begin{array}{c}0.158^{* *} \\
0.306^{* *} \\
1.36\end{array}$ & $\begin{array}{c}0.181^{* *} \\
0.200^{*} \\
0.17\end{array}$ & $\begin{array}{l}0.117 \\
0.078\end{array}$ \\
\hline The Need For Power & Gender & $\begin{array}{c}\text { Female } \\
\text { Male } \\
\text { F }\end{array}$ & & & $\begin{array}{c}0.257^{* *} \\
0.147 \\
0.99\end{array}$ & $\begin{array}{c}0.040 \\
0.194^{*}\end{array}$ & $\begin{array}{l}0.103 \\
0.032\end{array}$ & $\begin{array}{l}0.067 \\
0.096\end{array}$ & $\begin{array}{l}0.212^{* *} \\
0.159\end{array}$ & $\begin{array}{l}0.090 \\
0.177\end{array}$ & $\begin{array}{c}0.182^{* *} \\
0.198^{*} \\
0.14\end{array}$ & $\begin{array}{l}0.169 * * \\
0.176\end{array}$ & $\begin{array}{c}0.073 \\
0.210^{*}\end{array}$ \\
\hline The Need For Cognition & Gender & $\begin{array}{c}\text { Female } \\
\text { Male } \\
\mathrm{F}\end{array}$ & & & & $\begin{array}{c}0.196^{* *} \\
0.217^{*} \\
0.19 \\
\end{array}$ & $\begin{array}{l}0.136 * \\
0.046\end{array}$ & $\begin{array}{c}0.154^{*} \\
0.011\end{array}$ & $\begin{array}{c}0.227 * * \\
0.155\end{array}$ & $\begin{array}{c}0.206^{* *} \\
0.287^{* *} \\
0.75 \\
\end{array}$ & $\begin{array}{c}0.276^{* *} \\
0.299^{* *} \\
0.22 \\
\end{array}$ & $\begin{array}{c}0.235^{* *} \\
0.297^{* *} \\
0.58 \\
\end{array}$ & $\begin{array}{c}0.225^{* *} \\
0.274^{* *} \\
0.64 \\
\end{array}$ \\
\hline $\begin{array}{c}\text { Communicative } \\
\text { competence at } \\
\text { native language } / \mathrm{s}\end{array}$ & Gender & $\begin{array}{c}\text { Female } \\
\text { Male } \\
\text { F }\end{array}$ & & & & & $\begin{array}{l}0.074 \\
0.067\end{array}$ & $\begin{array}{c}0.228 * * \\
0.105\end{array}$ & $\begin{array}{c}0.258^{* *} \\
0.198^{*} \\
0.55\end{array}$ & $\begin{array}{c}0.352^{* *} \\
0.258^{* *} \\
0.06\end{array}$ & $\begin{array}{c}0.435^{* *} \\
0.302^{* *} \\
1.33 \\
\end{array}$ & $\begin{array}{c}0.462^{* *} \\
0.351^{* * *} \\
1.14\end{array}$ & $\begin{array}{c}0.186^{* *} \\
0.175\end{array}$ \\
\hline $\begin{array}{c}\text { Communicative } \\
\text { competence at a } \\
\text { foreign language } / \mathrm{s}\end{array}$ & Gender & $\begin{array}{c}\text { Female } \\
\text { Male } \\
\mathrm{F}\end{array}$ & & & & & & $\begin{array}{l}0.104 \\
0.086\end{array}$ & $\begin{array}{c}0.223 * * \\
0.063\end{array}$ & $\begin{array}{l}0.079 \\
0.040\end{array}$ & $\begin{array}{l}0.064 \\
0.111\end{array}$ & $\begin{array}{l}0.072 \\
0.189\end{array}$ & $\begin{array}{l}0.135 * \\
0.143\end{array}$ \\
\hline $\begin{array}{l}\text { Mathematics-based } \\
\text { competence at science } \\
\text { and technology }\end{array}$ & Gender & $\begin{array}{c}\text { Female } \\
\text { Male } \\
\mathrm{F}\end{array}$ & & & & & & & $\begin{array}{c}0.429 \text { ** } \\
0.339^{* *} \\
0.91\end{array}$ & $\begin{array}{c}0.433^{* *} \\
0.351^{* *} \\
0.84\end{array}$ & $\begin{array}{c}0.313^{* *} \\
0.333^{* *} \\
0.19 \\
\end{array}$ & $\begin{array}{c}0.375^{* *} \\
0.401^{* *} \\
0.26 \\
\end{array}$ & $\begin{array}{l}0.098 \\
0.175\end{array}$ \\
\hline Digital competence & Gender & $\begin{array}{c}\text { Female } \\
\text { Male } \\
\text { F }\end{array}$ & & & & & & & & $\begin{array}{l}0.489^{* *} \\
0.388^{* *} \\
1.08\end{array}$ & $\begin{array}{c}0.381 \text { ** } \\
0.292^{\text {** }} \\
0.87\end{array}$ & $\begin{array}{c}0.476^{* *} \\
0.332^{\text {** }} \\
1.49\end{array}$ & $\begin{array}{c}0.282 \text { ** } \\
0.266 * * \\
0.15\end{array}$ \\
\hline $\begin{array}{l}\text { The competence of learning } \\
\text { to learn }\end{array}$ & Gender & $\begin{array}{c}\text { Female } \\
\text { Male } \\
\mathrm{F}\end{array}$ & & & & & & & & & $\begin{array}{c}0.570^{* *} \\
0.540^{* *} \\
0.38\end{array}$ & $\begin{array}{l}0.615^{\text {** }} \\
0.536^{\text {** }} \\
1.02\end{array}$ & $\begin{array}{c}0.304 * * \\
0.274^{* *} \\
0.28\end{array}$ \\
\hline $\begin{array}{l}\text { The competence of social } \\
\text { citizenship awareness }\end{array}$ & Gender & $\begin{array}{c}\text { Female } \\
\text { Male } \\
\mathrm{F}\end{array}$ & & & & & & & & & & $\begin{array}{c}0.647^{* *} \\
0.543^{\text {** }} \\
1.4\end{array}$ & $\begin{array}{c}0.300^{* *} \\
0.213^{*} \\
0.87\end{array}$ \\
\hline $\begin{array}{l}\text { The competence of the } \\
\text { sense of initiative } \\
\text { and entrepreneurship }\end{array}$ & Gender & $\begin{array}{l}\text { Female } \\
\text { Male } \\
\mathrm{F}\end{array}$ & & & & & & & & & & & $\begin{array}{c}0.438 * * \\
0.389 * * \\
0.51\end{array}$ \\
\hline
\end{tabular}


Table 11. Relationship of teacher candidates' lifelong learning competence and basic motivation resources based on student status or not.

\begin{tabular}{|c|c|c|c|c|c|c|c|c|c|c|c|c|c|}
\hline & & & 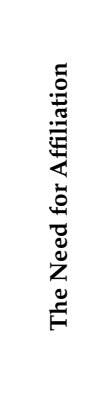 & 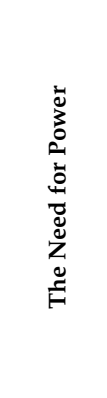 & 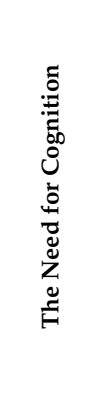 & 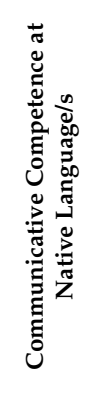 & 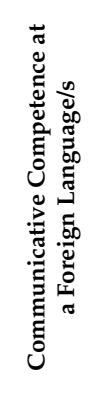 & 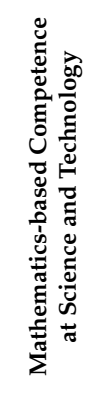 & 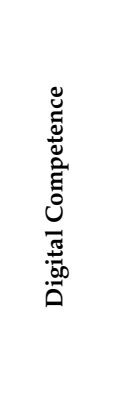 & 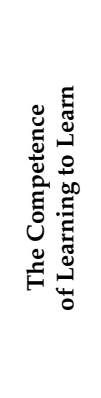 & 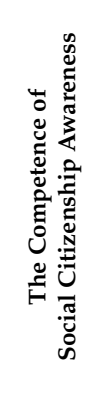 & 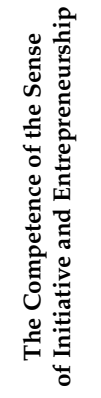 & 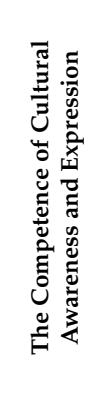 \\
\hline & & Student & 0.168 & $0.214^{*}$ & $0.358^{* *}$ & 0.086 & -0.046 & $0.384^{* *}$ & 0.120 & $0.315^{* *}$ & $0.261 *$ & $0.375^{* *}$ & 0.106 \\
\hline The Need For Achievement & Student or not? & $\begin{array}{c}\text { Non Student } \\
\text { F }\end{array}$ & $0.201 * *$ & $\begin{array}{c}0.166^{* *} \\
0.4\end{array}$ & $\begin{array}{c}0.298^{* *} \\
0.54\end{array}$ & $0.280^{* *}$ & 0.049 & $\begin{array}{c}0.216^{* *} \\
1.49\end{array}$ & $0.275^{* *}$ & $\begin{array}{c}0.329 * * \\
0.13\end{array}$ & $\begin{array}{c}0.282 * * \\
0.18\end{array}$ & $\begin{array}{c}0.325^{* *} \\
0.46\end{array}$ & $0.216^{* *}$ \\
\hline & & Student & & 0.017 & 0.24 & 0.095 & -0.014 & -0.012 & 0.199 & $0.259 *$ & 0.197 & 0.198 & 0.059 \\
\hline The Need For Affiliation & Student or not? & $\begin{array}{c}\text { Non Student } \\
\text { F }\end{array}$ & & 0.004 & $0.268^{* *}$ & $0.125 *$ & -0.095 & 0.062 & 0.095 & $\begin{array}{c}0.173 * * \\
0.73\end{array}$ & $0.209 * *$ & $0.192 * *$ & 0.145 * \\
\hline The Need For Power & Student or not? & $\begin{array}{c}\text { Student } \\
\text { Non Student } \\
\text { F }\end{array}$ & & & $\begin{array}{c}0.219 * \\
0.216^{* *} \\
0.03\end{array}$ & $\begin{array}{l}-0.206 \\
0.148\end{array}$ & $\begin{array}{l}0.153 \\
0.054\end{array}$ & $\begin{array}{l}0.104 \\
0.056\end{array}$ & $\begin{array}{c}0.227^{*} \\
0.196^{* *} \\
0.26\end{array}$ & $\begin{array}{l}0.115 \\
0.095\end{array}$ & $\begin{array}{c}0.184 \\
0.176^{* *}\end{array}$ & $\begin{array}{c}0.126 \\
0.175^{* *}\end{array}$ & $\begin{array}{c}0.065 \\
0.120^{*}\end{array}$ \\
\hline The Need For Cognition & Student or not? & $\begin{array}{c}\text { Student } \\
\text { Non Student } \\
\text { F }\end{array}$ & & & & $\begin{array}{c}0.118 \\
0.233 \text { ** }\end{array}$ & $\begin{array}{l}0.102 \\
0.077\end{array}$ & $\begin{array}{l}0.092 \\
0.104\end{array}$ & $\begin{array}{c}0.231^{*} \\
0.206^{* *} \\
0.21\end{array}$ & $\begin{array}{c}0.116 \\
0.266^{* *}\end{array}$ & $\begin{array}{l}0.228^{*} \\
0.297^{* *} \\
0.06\end{array}$ & $\begin{array}{c}0.262 * \\
0.252 * * \\
0.09\end{array}$ & $\begin{array}{c}0.205 \\
0.269^{* *}\end{array}$ \\
\hline $\begin{array}{c}\text { Communicative competence at } \\
\text { native language/s }\end{array}$ & Student or not? & $\begin{array}{c}\text { Student } \\
\text { Non Student } \\
\text { F }\end{array}$ & & & & & $\begin{array}{l}0.035 \\
0.039\end{array}$ & $\begin{array}{c}0.255^{*} \\
0.147^{*} \\
0.91\end{array}$ & $\begin{array}{c}0.047 \\
0.270^{* *}\end{array}$ & $\begin{array}{c}0.243 * \\
0.347^{* *} \\
0.92\end{array}$ & $\begin{array}{l}0.333^{* *} \\
0.407^{* *} \\
0.69\end{array}$ & $\begin{array}{c}0.355^{* *} \\
0.440^{* *} \\
1\end{array}$ & $\begin{array}{c}0.132 \\
0.31^{* *}\end{array}$ \\
\hline $\begin{array}{l}\text { Communicative competence at } \\
\text { a foreign language } / \mathrm{s}\end{array}$ & Student or not? & $\begin{array}{c}\text { Student } \\
\text { Non Student } \\
\text { F }\end{array}$ & & & & & & $\begin{array}{l}0.030 \\
0.107\end{array}$ & $\begin{array}{c}0.191 \\
0.143 *\end{array}$ & $\begin{array}{l}0.044 \\
0.033\end{array}$ & $\begin{array}{l}0.028 \\
0.070\end{array}$ & $\begin{array}{l}0.043 \\
0.111\end{array}$ & $\begin{array}{c}0.139 \\
0.121 *\end{array}$ \\
\hline $\begin{array}{l}\text { Mathematics-based } \\
\text { competence at science } \\
\text { and technology }\end{array}$ & Student or not? & $\begin{array}{c}\text { Student } \\
\text { Non Student } \\
\text { F }\end{array}$ & & & & & & & $\begin{array}{l}0.411^{* *} \\
0.393^{* *} \\
0.17\end{array}$ & $\begin{array}{c}0.526^{* *} \\
0.358^{* *} \\
1.69\end{array}$ & $\begin{array}{c}0.373^{* *} \\
0.288^{* *} \\
0.77\end{array}$ & $\begin{array}{l}0.461^{* *} \\
0.346^{* *} \\
1.11\end{array}$ & $\begin{array}{c}0.104 \\
0.130 *\end{array}$ \\
\hline Digital competence & Student or not? & $\begin{array}{c}\text { Student } \\
\text { Non Student } \\
\text { F }\end{array}$ & & & & & & & & $\begin{array}{l}0.503^{* *} \\
0.431^{* *} \\
0.74\end{array}$ & $\begin{array}{c}0.396^{* *} \\
0.351^{* *} \\
0.42\end{array}$ & $\begin{array}{c}0.503^{* *} \\
0.405^{* *} \\
0.99\end{array}$ & $\begin{array}{l}0.337^{* *} \\
0.252^{* *} \\
0.75\end{array}$ \\
\hline $\begin{array}{l}\text { The competence of learning } \\
\text { to learn }\end{array}$ & Student or not? & $\begin{array}{c}\text { Student } \\
\text { Non Student } \\
\text { F }\end{array}$ & & & & & & & & & $\begin{array}{l}0.557^{* *} \\
0.562^{* *} \\
0.06\end{array}$ & $\begin{array}{l}0.633^{* *} \\
0.575^{* *} \\
0.74\end{array}$ & $\begin{array}{c}0.072 \\
0.386 \text { ** }\end{array}$ \\
\hline $\begin{array}{l}\text { The competence of social } \\
\text { citizenship awareness }\end{array}$ & Student or not? & $\begin{array}{c}\text { Student } \\
\text { Non Student } \\
\text { F }\end{array}$ & & & & & & & & & & $\begin{array}{c}0.637^{* *} \\
0.608^{* *} \\
0.38\end{array}$ & $\begin{array}{l}0.221 * \\
0.317^{* *} \\
0.83\end{array}$ \\
\hline $\begin{array}{l}\text { The competence of the sense of } \\
\text { initiative and entrepreneurship }\end{array}$ & Student or not? & $\begin{array}{c}\text { Student } \\
\text { Non Student } \\
\text { F }\end{array}$ & & & & & & & & & & & $\begin{array}{l}0.350 * * \\
0.462 * * \\
1.08\end{array}$ \\
\hline
\end{tabular}

${ }^{* *}$ Correlation is significant at the 0.01 level (2-tailed). ${ }^{*}$ Correlation is significant at the 0.05 level (two-tailed). 
When examined in terms of being a university student or not basis, there is no significant relationship between the "communicative competence at a foreign language/s" sub-dimension of the "Key Competences for Lifelong Learning Scale" and all sub-dimensions of the "Basic Motivation Resources Scale".

There is significant relationship between the "need for achievement" sub-dimension of the "Basic Motivation Resources Scale" and sub-dimensions of the "Key Competences for Lifelong Learning Scale" except for "communicative competence at a foreign language/s" sub-dimension of the "Key Competences for Lifelong Learning Scale" for university student teacher candidates.

A more significant relation was found between the "Key Competences for Lifelong Learning Scale" and the "Basic Motivation Resources Scale" in favor of university student teacher candidates. Generally, according to results of the Fisher r-to-z transformation test, made to compare correlations that are significant in the scales' correlations, based on gender and to be a university student or not, it was determined that there was no meaningful difference in terms of relations between the "Key Competences for Lifelong Learning Scale" and the "Basic Motivation Resources Scale"

\section{Discussion}

In this research, in which the purpose was to determine the teacher candidates' life-long learning competence and the main motivation sources, teacher candidates' main motivation sources were found to be above the average in all sub-dimensions of the scales. Findings of the studies conducted by Gömleksiz and Serhatlıoğlu [37] and Alemdağ, Öncü, and Yılmaz [64] overlap with the findings of this research, and it was determined that the academic motivation levels of teacher candidates were moderate and high and that motivation levels were low. In the studies conducted by Altinkurt, Yilmaz, and Erol [65] and Turhan and Agaoglu [66], teacher candidates' motivation levels for the teaching profession were found to be high. In the research conducted by Ürün-Karahan [67], the teacher candidates' motivation towards reading was found to be high. These results are also consistent with the findings of this study. Similarly, the study by Klassen et al. [68] concluded that both Canadian and Omani teacher candidates had high personal motivation levels for teaching. It was also emphasized that socio-cultural factors, especially the religion factor, plays a key role in determining the motivation levels of teacher candidates. In the research conducted by Kim and Cho [69], teacher candidates' internal motivations, identified motivations, and sense of efficacy are closely related. In addition, in the survey conducted by Gündoğdu and Yavuzer [70], the "relationship needs" subscale had the highest scores for teacher candidates in the "basic psychological needs scale", and this finding is consistent with the findings of this study in which teacher candidates had the highest score in the "attachment needs" subscale in "basic motivational needs scale". Nevertheless, both of these sub-dimensions are related to interpersonal communication. On the contrary to the findings of this research and the research done by Gündoğdu and Yavuzer [70] and the study carried out by Gençtarım and Tay [71] reached the conclusion that the need for success was at the highest level for teacher candidates, moreover, the sub-dimension they found at the minimum level were the "relationship needs" for teacher candidates. Additionally, Tu, Liu, and Wu [7] indicate that design thinking increases individuals' motivation level to learn.

In this study, it was determined that the teacher candidates' "Key Competences for Lifelong Learning Scale" is above the average in all dimensions except the "sufficiency in communication in foreign-language" sub-dimension. When the literature is examined, it appears that there are other studies $[46,49,50,72-82]$ which found out that the teacher candidates' lifelong learning competence are high. Additionally, in the literature, there are studies $[67,83]$ indicating that teacher candidates' learning tendencies are moderate. In addition to these, there are also studies $[84,85]$ demonstrating that teacher candidates have a low level of life-long learning competence. It is thought that the reasons for the differences in the results of these studies on teacher candidates' lifelong learning competence are the use of different measurement tools and the difference between the sample groups. 
In this study, teacher candidates scored "below average" in the subscale of "sufficiency in communication in foreign-language" in "Key Competences for Lifelong Learning Scale", unlike other subscales. Supporting this finding of this study, there are studies in the literature [86-88] that indicate problems with foreign language education. Research conducted by Dinçer and Yeşilyurt [89] stated that teacher candidates who studied in the department of English language teaching found their English communication skills to be inadequate despite their high motivation to use English. In addition, there are studies in the literature indicating that English language teachers have problems with speaking English [90-92]. Ariyanti [93] notes that English teacher candidates' problems in speaking English are due to psychological reasons. Supporting Ariyanti [93], the research conducted by Öztürk and Gürbüz [94] and Tercan and Dikilitaş [95] showed that English teacher candidates had a high level of English speaking concerns. It is emphasized by Tsiplakides and Keramida [96] that in order to develop the foreign language speaking skills, the concerns regarding the subject should be addressed. Additionally, in this research there is no significant relationship between "communicative competence at a foreign language/s" sub-dimension of the "Key Competences for Lifelong Learning Scale" and all sub-dimensions of the "Basic Motivation Resources Scale". These results show that teacher candidates do not care much about foreign languages. The teacher candidates' concerns about foreign languages and their inadequacy can be shown as the reason for this.

When the gender variable is taken into consideration, a significant difference was found in favor of male teacher candidates in the "Key Competences for Lifelong Learning Scale" and the "sufficiency in communication in foreign-language" subscale for teacher candidates. In the research conducted by Izgi and Koç [49], in "teachers should encourage students to learn foreign language" item of "lifelong learning scale", a significant difference was found in favor of female teacher candidates. This contradicts with the findings of this research. In this study, a significant difference was found in favor of female teacher candidates in the "sufficiency in learning to learn", "cultural awareness and expression sufficiency", sub-dimensions of the "Lifelong Learning Tendency Scale". In the research conducted by Izgi and Koç [49] a significant difference was found in favor of female teacher candidates in "the teacher should raise individuals who determine the ways of accessing information and choose and classify the necessary information (information literacy)", "the teacher should be the one who learns lifelong with students rather than being the information distributor", "teachers must have the ability of creative and critical thinking" items of the "life-long learning scale". Since these items are related to the concept of "learning to learn", it can be said that the findings of the research done by Izgi and Koç [49] overlap with the findings of this research. There are also studies [76,85,97-99] in the literature which show that teacher candidates' lifelong learning competence did not change according to gender. When the literature is examined, there are studies $[46,47]$ which show that there is a significant difference in favor of female teacher candidates in terms of their lifelong learning competence. Additionally, it is also seen that there are studies on the teacher candidates' lifelong learning competence [48] indicating that there is a significant difference in favor of male teacher candidates. In the literature, studies which examine the effect of gender on life-long learning levels of teacher candidates seem to be inconclusive. This situation in the literature is considered to be due to differences in the sub-dimensions of the used measuring instruments.

In addition, significant differences were found in the "the need for achievement", "the need for affiliation", and "the need for cognition" sub-dimensions of the "Basic Motivation Resources Scale" in favor of female teacher candidates. In the study carried out by Aydıner [100], female university students were found to give more importance to the personal development and social responsibility than males. The finding of the study carried out by Aydiner [100] is parallel to the findings of this research. In studies conducted by Çivitçi [101] and Baysal and Buluş [102] it was revealed that the need for the success of university students did not change according to gender. In terms of the need for thinking, the significant difference in favor of female students determined by Gençdoğan [103] and Demirtaş-Madran [104] supports the findings of this research. Supporting the findings of this study and the studies carried out by Gençdoğan [103] and Demirtaş-Madran [104], the research performed by 
Tanaka, Panter, and Winborne [105] also found that the need for thinking is in favor of females. In the study conducted by Cenkseven and Akar-Vural [106], it was determined that the need for thinking did not change according to the gender. There are also studies which support the finding that the need for thinking does not change according to the gender [107-109].

In this study, it was found that the fact that the female scores were higher in "the need for affiliation" sub-dimension of the "Basic Motivation Resources Scale" might be the result of the fact that the secure affiliation levels of males are higher in general [110-112]. Since males have a higher level of secure affiliation, the need for affiliation decreases. As females' secure affiliation levels are low, their affiliation needs are increasing. Of course, this can be related to the meaning that the individuals attribute to the gender in their society $[113,114]$.

A significant difference was found between "communicative competence at native language", "mathematics-based competence at science and technology", "the competence of learning to learn", and "the competence of the sense of initiative and entrepreneurship" sub-dimension of the "Key Competences for Lifelong Learning Scale" in favor of teacher candidates who are continuing their university education. The fact that teacher candidates' ability to use local language, basic mathematics knowledge, learning, and entrepreneurship skills are significantly higher than those of university graduate teacher candidates can be interpreted in the way that they are still connected with the classes and that they are younger. There is a close relationship between pursuing technological developments and success [115]. In the study performed by Grilo and Thurik [116], it was stated that the lack of recognizing what difficulties individuals will face when they will attend the professional life may have a positive effect, and this statement shows similarity with the findings of this research. Moreover, in the study conducted by Korkmaz [117], the university students' entrepreneurship levels were found to be high.

Significant difference was found in the "the need for achievement" sub-dimension of the "Basic Motivation Resources Scale" in favor of teacher candidates who are continuing their university education. The need for achievement is significantly higher for teacher candidates who are continuing their university education. This is thought to have an important share in the need for success in the exams for graduating from their schools and in the examinations where students are required to attend after the university. In addition, in this study, teacher candidates' "the need for achievement" sub-dimension of the "Basic Motivation Resources Scale" was related to all of the sub-dimensions except for "sufficiency in communication in foreign language" and the sub-dimension of the "Lifelong Learning Tendency Scale". This can be regarded as a demonstration that teacher candidates' achievement needs are addressed to the exams in their own language. More significant relation was found between the "Key Competences for Lifelong Learning Scale" and the "Basic Motivation Resources Scale" in favor of university student teacher candidates. This result shows that the teacher candidates' continuing university education has a higher relationship with their basic needs so that they can have the sufficiency in fields of competence that they will need.

Generally, according to the results of the Fisher r-to-z transformation test, made to compare correlations that are significant in the scales correlations, based on gender and to be a university student or not. It was determined that there was no significant difference in terms of relationships between the "Key Competences for Lifelong Learning Scale" and the "Basic Motivation Resources Scale". Based on this result, it can be concluded that the relationship between lifelong learning sufficiency of teacher candidates and their basic motivation sources do not depend on their being university students or on their genders.

Author Contributions: Conceptualization: G.I. and M.E.; methodology: G.I.; software: G.I.; validation: G.I. and M.E.; formal analysis: G.I.; investigation: G.I.; resources: M.E.; data curation: G.I.; writing-original draft preparation: M.E.; writing—review and editing: M.E.; visualization: M.E.; supervision: G.I. and M.E.

Funding: This research received no external funding.

Conflicts of Interest: The authors declare no conflict of interest. 


\section{References}

1. Kara, A. Öğrenmeye ilişkin tutum ölçeğinin geliştirilmesi. Elektronik Sosyal Bilimler Dergisi 2010, 9, 49-62.

2. Duman, A. Yetişkinler Eğitimi; Ütopya Yayınevi: Ankara, Turkey, 2000.

3. Billett, S. The perils of confusing lifelong learning with lifelong education. Int. J. Lifelong Educ. 2010, 29, 401-413. [CrossRef]

4. Bee, H.; Body, D. Çocuk Gelişimi Psikolojisi; Gündüz, O., Translator; Kaknüs Yayınları: İstanbul, Turkey, 2009.

5. Santrock, J.W. Educational Psycology, 2nd ed.; McGraw-Hill Company, Inc.: Dallas, TX, USA, 2004.

6. Hargreaves, A.; Fink, D. Sustainable Leadership; Jossey-Bass: San Francisco, CA, USA, 2006.

7. Tu, J.-C.; Liu, L.-X.; Wu, K.-Y. Study on the learning effectiveness of Stanford design thinking in integrated design education. Sustainability 2018, 10, 2649. [CrossRef]

8. Gülmez, A.; Titrek, O.; Özkorkmaz, M.A. The situation of lifelong education in Turkey. Int. J. Lifelong Educ. Leadersh. 2015, 1, 21-31. [CrossRef]

9. Kolb, D.A. Experiential Learning: Experience as the Source of Learning and Development; FT Press: Upper Saddle River, NJ, USA, 2014.

10. Swanson, R.A.; Holton, E.; Holton, E.F. Foundations of Human Resource Development; Berrett-Koehler Publishers: Oakland, CA, USA, 2001.

11. Abukari, A. Conceptualising Lifelong Learning: A Reflection on Lifelong Learning. In Proceedings of the 1st International Euredocs Conference Sciences: Transformations Experienced by Higher Education and Research Institutions in European Countries, Paris, France, 24-26 June 2004; pp. 1-21. Available online: euredocs.sciences-po.fr/en/conference/2004/abdulai_abukari.pdf (accessed on 15 June 2018).

12. Crick, R.D.; Broadfoot, P.; Claxton, G. Developing an effective lifelong learning inventory: The ELLI project. Assess. Educ. Princ. Policy Pract. 2004, 11, 247-272. [CrossRef]

13. Poyraz, H.; Titrek, O. Türkiye'de hayat boyu ögrenmenin gelistirilmesi. Abant Izzet Baysal Universitesi Egitim Fakultesi Dergisi 2013, 13, 115-131.

14. Laal, M.; Laal, A.; Aliramaei, A. Continuing education; lifelong learning. Procedia Soc. Behav. Sci. 2014, 116, $4052-4056$. [CrossRef]

15. Laal, M. Benefits of lifelong learning. Procedia Soc. Behav. Sci. 2012, 46, 4268-4272. [CrossRef]

16. Akçay, R.C.; Yıldırım, R. Evaluating the continuing education centers in terms of lifelong learning. Procedia Soc. Behav. Sci. 2014, 116, 1756-1762. [CrossRef]

17. Bryce, J. Schools and lifelong learners. In Lifelong Learning Participation and Equity; Chapman, J., Cartwright, P., McGilp, E.J., Eds.; Springer: Dordrecht, The Netherlands, 2006; pp. 243-263. ISBN 978-90-481-7339-6.

18. The Organisation for Economic Cooperation and Development. Lifelong Learning for All; OECD: Paris, France, 2001.

19. Kulich, J. Lifelong education and the universities: A Canadian perspective. Int. J. Lifelong Educ. 1982, 1, $123-142$. [CrossRef]

20. Dash, G.; Mohan, A.K. Education for sustainability: Perception of teachers and practices in urban primary schools of Mysore. Gyanodaya J. Progress. Educ. 2017, 10, 9-17. [CrossRef]

21. Ryan, R.M.; Deci, E.L. Intrinsic and extrinsic motivations: Classic definitions and new directions. Contemp. Educ. Psychol. 2000, 25, 54-67. [CrossRef] [PubMed]

22. Gaymer, D.M. Continuing education and lifelong learning trends. In Encyclopedia of Management, 5th ed.; Helms, M.M., Ed.; Thomson Gale Publishing: Farmington Hills, MI, USA, 2006; pp. 128-131.

23. Hargreaves, A. Sustainable leadership and development in education: Creating the future, conserving the past. Eur. J. Educ. 2007, 42, 223-233. [CrossRef]

24. Amzat, I.H.; Al-Mahruqi, S.H.; Teslikhan, M.; Omairi, T.A. Engaging teachers in lifelong learning in Oman for knowledge growth and development: Government roles and higher institutions. In Teacher Empowerment Toward Professional Development and Practices; Amzat, I., Valdez, N., Eds.; Springer: Singapore, 2017; pp. 135-151.

25. Akbaba, S. Eğitimde motivasyon. Atatürk Üniversitesi Kazım Karabekir Ĕ̆itim Fakültesi Dergisi 2006, 13, $343-361$.

26. Emily, L.R. Motivation: A Literature Review (Research Report); Pearson: New York, NY, USA, 2011.

27. Rhodes, R.E.; Fiala, B. Building motivation and sustainability into the prescription and recommendations for physical activity and exercise therapy: The evidence. Physiother. Theory Pract. 2009, 25, 424-441. [CrossRef] [PubMed] 
28. Guay, F.; Chanal, J.; Ratelle, C.F.; Marsh, H.W.; Larose, S.; Boivin, M. Intrinsic, identified, and controlled types of motivation for school subjects in young elementary school children. Br. J. Educ. Psychol. 2010, 80, 711-735. [CrossRef] [PubMed]

29. Bentley, T. Takımınızın Yeteneklerini Geliştirmede Insanları Motive Etme; Yıldırım, O., Translator; Hayat Yayınları: İstanbul, Turkey, 2006.

30. Oudeyer, P.Y.; Kaplan, F. How can we define intrinsic motivation? In Proceedings of the 8th International Conference on Epigenetic Robotics: Modeling Cognitive Development in Robotic Systems, Brighton, UK, 30-31 July 2008; Lund University Cognitive Studies: Lund, Sweden, 2008.

31. Woolfolk, A.E. Educational Psychology, 9th ed.; Pearson: New York, NY, USA, 2004.

32. Mercanlığlu, Ç. Örgütlerde performans yönetimi ile işgörenlerin motivasyonu arasındaki ilişki. Organizasyon ve Yönetim Bilimleri Dergisi 2012, 4, 41-52.

33. Ada, Ş.; Akan, D.; Ayık, A.; Yıldırım, İ.; Yalçın, S. Öğretmenlerin motivasyon etkenleri. Atatürk Üniversitesi Sosyal Bilimler Enstitüsü Dergisi 2013, 17, 151-166.

34. Uyulgan, M.A.; Akkuzu, N. An overview of student teachers' academic intrinsic motivation. Educ. Sci. Theory Pract. 2014, 14, 24-32. [CrossRef]

35. Lin, Y.G.; McKeachie, W.J.; Kim, Y.C. College student intrinsic and/or extrinsic motivation and learning. Learn. Individ. Differ. 2003, 13, 251-258. [CrossRef]

36. Deci, E.L. Intrinsic Motivation; Plenum: New York, NY, USA, 1975.

37. Gömleksiz, M.N.; Serhatlığlu, B. Öğretmen adaylarinin akademik motivasyon düzeylerine ilişkin görüşleri. Türkiye Sosyal Araştırmalar Dergisi 2014, 173, 99-128.

38. Yıldız, M.; Akyol, H. İlköğretim 5. sınıf öğrencilerinin okuduğunu anlama, okuma motivasyonu ve okuma alışkanlıkları arasındaki ilişki. Gazi Üniversitesi Gazi Ĕ̆itim Fakültesi Dergisi 2014, 31, 793-815.

39. Yazıcı, H. Öğretmenlik mesleği, motivasyon kaynaklari ve temel tutumlar: Kuramsal bir bakiş. Kastamonu Ĕ̆itim Dergisi 2009, 17, 33-46.

40. Mottaz, J.C. The Relative Importance of Intrinsic and Extrinsic Rewards as Determinants of Wok Satisfaction. Sociol. Q. 1985, 26, 365-385. [CrossRef]

41. Dweck, C.S.; Leggett, E.L. A social-cognitive approach to motivation and personality. Psychol. Rev. 1988, 95, $256-273$. [CrossRef]

42. Polat, C.; Odabaş, H. Bilgi toplumunda yaşam boyu öğrenmenin anahtarı: Bilgi okuryazarlı̆̆ı. In Proceedings of the Küreselleşme, Demokratikleşme ve Türkiye Uluslararası Sempozyumu Bildiri Kitabı (International Symposium on Globalization, Democratization and Turkey Proceedings), Antalya, Turkey, 27-30 March 2008; pp. 596-606.

43. Mardapi, D.; Herawan, T. Assessing teacher competence and its follow-up to support professional development sustainability. J. Teach. Educ. Sustain. 2018, 20, 106-123.

44. Uzunboylu, H.; Selcuk, G. Lifelong learning competency perceptions of teacher candidates according to a teacher training program. Anthropologist 2016, 24, 119-125. [CrossRef]

45. Gencel, İ.E. Öğretmen adaylarının yaşam boyu öğrenme yeterliklerine yönelik algıları. Ĕ̆itim ve Bilim 2013, 38, 237-252.

46. Erdoğan, D.G. Öğretmen adaylarının yaşam boyu öğrenme eğilimlerine etki eden faktörler. Ph.D. Thesis, Abant İzzet Baysal University, Bolu, Turkey, 2014.

47. Kılıç, Ç. Öğretmen adaylarının yaşam boyu öğrenmeye yönelik algıları. Eğitim ve Öğretim Araştırmaları Dergisi 2014, 3, 79-87.

48. Diker-Coşkun, Y.; Demirel, M. Üniversite öğrencilerinin yaşam boyu öğrenme eğilimleri. Hacettepe Üniversitesi Eğitim Fakültesi Dergisi 2012, 42, 108-120.

49. İzci, E.; Koç, S. Öğretmen adaylarının yaşam boyu öğrenmeye ilişkin görüşlerinin belirlenmesi. Adıyaman Üniversitesi Sosyal Bilimler Enstitüsü Dergisi 2012, 5, 101-114.

50. Şahin, M.; Akbaşlı, S.; Yanpar-Yelken, T. Key competences for lifelong learning: The case of prospective teachers. Educ. Res. Rev. 2010, 5, 545-556.

51. Antalyalı, Ö.L.; Bolat, Ö. Öğrenilmiş ihtiyaçlar bağlamında temel motivasyon kaynakları (TMK) ölçeğinin geliştirilmesi güvenirlik geçerlik analizi. Abant İzzet Baysal Üniversitesi Sosyal Bilimler Enstitüsü Dergisi 2017, 17, 83-114.

52. Yaman, F.; Yazar, T. Öğretmenlerin yaşam boyu öğrenme eğilimlerinin incelenmesi (Diyarbakır ili örneği). Kastamonu Educ. J. 2018, 23, 1553-1566. 
53. Kirby, J.R.; Knapper, C.; Lamon, P.; Egnatoff, W.J. Development of a scale to measure lifelong learning. Int. J. Lifelong Educ. 2010, 29, 291-302. [CrossRef]

54. Cho, J. The development of an alternative in-service programme for Korean science teachers with an emphasis on science-technology-society. Int. J. Sci. Educ. 2002, 24, 1021-1035. [CrossRef]

55. Uzunboylu, H.; Hursen, C. Evaluation of teachers' attitudes and perceptions of competence regarding lifelong learning. Croat. J. Educ. Hrvatski časopis za odgoj i obrazovanje 2013, 15, 177-204.

56. Fujitani, M.; Muta, H.; Ota, G. Measurement of the effect of in-service teacher training program for science education: A case study in Jordan. Educ. Technol. Res. 2011, 34, 1-13.

57. Ilgaz, G. If in-service education as lifelong education is important, how can be it routed: Evidence from TIMSS-2015 eighth classroom science teachers in Europe. In Proceedings of the 3rd International Conference on Lifelong Learning and Leadership for All (ICLEL 2017), Porto, Portugal, 12-14 September 2017; p. 119.

58. Asendorpf, J.B.; van de Schoot, R.; Denissen, J.J.A.; Hutteman, R. Reducing bias due to systematic attrition in longitudinal studies: The benefits of multiple imputation. Int. J. Behav. Dev. 2014, 38, 453-460. [CrossRef]

59. Peeters, M.; Zondervan-Zwijnenburg, M.; Vink, G.; van de Schoot, R. How to handle missing data: A comparison of different approaches. Eur. J. Dev. Psychol. 2015, 12, 377-394. [CrossRef]

60. Büyüköztürk, Ş. Sosyal bilimler için veri analizi el kitabl; PEGEM Akademi: Ankara, Turkey, 2011.

61. Cohen, J. Statistical Power Analysis for the Behavioral Sciences, 2nd ed.; Lawrence Erlbaum: Hillsdale, NJ, USA, 1988.

62. Website for Statistical Computation. Available online: http://vassarstats.net/rdiff.html (accessed on 14 April 2018).

63. Şencan, H. Sosyal ve Davranışsal Ölçümlerde Geçerlilik ve Güvenirlik; Seçkin Matbaası: Ankara, Turkey, 2005.

64. Alemdağ, C.; Öncü, E.; Yılmaz, A.K. Beden eğitimi öğretmeni adaylarinin akademik motivasyon ve akademik öz-yeterlilikleri. Spor Bilimleri Dergisi 2014, 25, 23-35.

65. Altınkurt, Y.; Yılmaz, K.; Erol, E. Pedagojik formasyon programı öğrencilerinin öğretmenlik mesleğine yönelik motivasyonları. Trakya Üniversitesi Eğitim Fakültesi Dergisi 2014, 4, 48-62.

66. Turhan, E.; Ağaoğlu, E. The level of motıvatıon of teacher candıdates at graduate school of educatıonal sciences and social sciences and 4'th year in faculty of educatıon-Akdeniz, Anadolu, Dumlupınar ve Akdeniz university case. Educ. Sci. 2011, 6, 1759-1774.

67. Ürün-Karahan, B. Öğretmen adaylarinin okumaya yönelik motivasyonlarinin çeşitli değişkenler açısından incelenmesi (Kafkas Üniversitesi örneği). Turk. Stud. 2015, 10/11, 1569-1586. [CrossRef]

68. Klassen, R.M.; Al-Dhafri, S.; Hannok, W.; Betts, S.M. Investigating pre-service teacher motivation across cultures using the Teachers' Ten Statements Test. Teach. Teach. Educ. 2011, 27, 579-588. [CrossRef]

69. Kim, H.; Cho, Y. Pre-service teachers' motivation, sense of teaching efficacy, and expectation of reality shock. Asia-Pac. J. Teach. Educ. 2014, 42, 67-81. [CrossRef]

70. Gündoğdu, R.; Yavuzer, Y. Eğitim fakültesi öğrencilerinin öznel iyi oluş ve psikolojik ihtiyaçlarının demografik değişkenlere göre incelenmesi. Mehmet Akif Ersoy Ĕ̆itim Fakültesi Dergisi 2012, 12, 115-131.

71. Gençtarım, D.; Bayram, T.A.Y. Sınıf öğretmeni adaylarının psikolojik ihtiyaçları. İlköğretim Online 2015, 14, 647-656.

72. Ayra, M. Öğretmenlerin yaşam boyu öğrenme eğilimlerinin mesleki öz yeterlik inançları ile ilişkisi. Master's Thesis, Amasya University, Amasya, Turkey, 2015.

73. Ergün, S.; Özata, S. Okul öncesi öğretmenliği bölümüne devam eden öğrencilerin yaşam boyu öğrenme eğilimleri. Int. J. Hum. Sci. 2016, 13, 1851-1861.

74. Garipağaoğlu, B.C. The effect of self-efficacy on the lifelong learning tendencies of Computer Education and Instructional Technologies pre-service teachers: A case study. Int. J. Hum. Sci. 2013, 10, 224-236.

75. Kuzu, S.; Demir, S.; Canpolat, M. Evaluation of lifelong learning tendencies of pre-service teachers in terms of some variables. J. Theory Pract. Educ. 2015, 11, 1089-1105.

76. Özgür, H. Öğretmen adaylarının yaşam boyu öğrenme yeterlikleri ve bilgi okuryazarlığı öz-yeterlikleri üzerine bir çalışma. Mersin Üniversitesi Ĕ̆itim Fakültesi Dergisi 2016, 12, 22-38. [CrossRef]

77. Pınarcık, Ö.; Danacı, M.; Deniz, M.E.; Eran, N. Okul öncesi öğretmenlerinin yaşam boyu öğrenme yeterliklerine yönelik algıları. Abant İzet Baysal Üniversitesi Ĕ̆itim Fakültesi Dergisi 2016, 16, 1966-1983.

78. Solmaz, D.Y.; Aydin, G. Evaluation of lifelong learning tendencies of pre-service teachers. Anthropologist 2016, 24, 55-63. [CrossRef]

79. Solmaz, D.Y. Relationship between Lifelong Learning Levels and Information Literacy Skills in Teacher Candidates. Univers. J. Educ. Res. 2017, 5, 939-946. [CrossRef] 
80. Yazar, T.; Keskin, İ. Examination of prospective teachers' digital competence in the context of lifelong learning. Uluslararası Ĕ̆itim Programları ve Öğretim Çalışmaları Dergisi 2016, 6, 133-150.

81. Özen, R.; Özturk, D.S.; Özturk, F. The relationship between pre-service teachers' lifelong learning tendencies and the quality of university life. Anthropologist 2016, 24, 105-112. [CrossRef]

82. Öztürk-Yurtseven, G.; Aldan-Karademir, Ç. Pedagojik formasyon eğitimi sertifika programındaki öğretmen adaylarının bireysel yenilikçilik düzeyleri ve yaşam boyu öğrenme eğilimleri. Eğitim Bilimleri Araştırmaları Dergisi-J. Educ. Sci. Res. 2017, 7, 189-206.

83. Özen, R.; Öztürk, D.S. The Relationship between pre-service teachers' lifelong learning tendencies and teaching profession anxiety levels. Univers. J. Educ. Res. 2016, 4, 7-15. [CrossRef]

84. Ekşioğlu, S.; Tarhan, S.; Gündüz, H.Ç. The relationships between self efficacy expectations and personality traits with lifelong learning tendency. Kastamonu Educ. J. 2017, 25, 1925-1940.

85. Tunca, N.; Şahin, S.A.; Aydin, O. Ögretmen adaylarının yaşam boyu ögrenme eğilimleri. Mersin Üniversitesi Egitim Fakültesi Dergisi 2015, 11, 432-446. [CrossRef]

86. Horwitz, E.K.; Horwitz, M.B.; Cope, J. Foreign language classroom anxiety. Mod. Lang. J. 1986, 70, $125-132$. [CrossRef]

87. Işık, A. Yabancı Dil Eğitiminde Yanlışlar Nereden Kaynaklanıyor? J. Lang. Linguist. Stud. 2008, 4, 15-26.

88. Kirkgoz, Y. English language teaching in Turkey: Policy changes and their implementations. Reg. Lang. Cent. J. 2007, 38, 216-228. [CrossRef]

89. Dincer, A.; Yesilyurt, S. Pre-service English teachers' beliefs on speaking skill based on motivational orientations. Engl. Lang. Teach. 2013, 6, 88. [CrossRef]

90. Al Hosni, S. Speaking Difficulties Encountered by Young EFL Learners. Int. J. Stud. Engl. Lang. Lit. IJSELL 2014, 2, 22-30.

91. Ay, S. Young adolescent students' foreign language anxiety in relation to language skills at different levels. J. Int. Soc. Res. 2010, 3, 83-92.

92. Liu, M.; Jackson, J. An exploration of Chinese EFL learners' unwillingness to communicate and foreign language anxiety. Mod. Lang. J. 2008, 92, 71-86. [CrossRef]

93. Ariyanti, A. Psychological factors affecting EFL students' speaking performance. ASIAN TEFL: J. Lang. Teach. Appl. Linguist. 2016, 1, 77-88. [CrossRef]

94. Öztürk, G.; Gürbüz, N. Speaking anxiety among Turkish EFL learners: The case at a state university. J. Lang. Linguist. Stud. 2014, 10, 1-17.

95. Tercan, G.; Dikilitaş, K. EFL students' speaking anxiety: A case from tertiary level students. ELT Res. J. 2015, 4, 16-27.

96. Tsiplakides, I.; Keramida, A. Helping students overcome foreign language speaking anxiety in the English classroom: Theoretical issues and practical recommendations. Int. Educ. Stud. 2009, 2, 39-44. [CrossRef]

97. Oral, B.; Yazar, T. Öğretmen adaylarının yaşam boyu öğrenmeye ilişkin algılarının çeşitli değişkenlere göre incelenmesi. Elektronik Sosyal Bilimler Dergisi 2015, 14, 1-11. [CrossRef]

98. Savuran, Y. İngilizce öğretmen adaylarının mentorlarına kıyasla yaşam boyu öğrenme becerileri. Master's Thesis, Hacettepe University, Ankara, Turkey, 2014.

99. Yaman, F. Öğretmenlerin yaşam boyu öğrenme eğilimlerinin incelenmesi (Diyarbakır ili örneği). Master's Thesis, Dicle University, Diyarbakır, Turkey, 2014.

100. Aydıner, B.B. Üniversite öğrencilerinin yaşam amaçlarının alt boyutlarının genel öz-yeterlik, yaşam doyumu ve çeşitli değişkenlere göre incelenmesi. Master's Thesis, Sakarya Üniversitesi Eğitim Bilimleri Enstitüsü, Adapazarı, Turkey, 2011.

101. Çivitçi, A. Üniversite öğrencilerinde genel yaşam doyumu ve psikolojik ihtiyaçlar arasindaki ilişkiler. Çukurova Universitesi Sosyal Bilimler Enstitüsü Dergisi 2012, 2, 321-336.

102. Baysal, A.; Buluş, M. PDR öğrencilerinin psikolojik gereksinim düzeyleri. Pamukkale Üniversitesi Ĕ̆itim Fakültesi Dergisi 2001, 9, 19-27.

103. Gençdoğan, B. Üniversite öğrencilerinin düşünme ihtiyaçlarının bazı değişkenler açısından incelenmesi. Cumhuriyet Üniversitesi Sosyal Bilimler Dergisi 2001, 25, 227-234.

104. Demirtaş-Madran, H.A. Cinsiyet, cinsiyet rolü yönelimi ve düşünme ihtiyacı. Türk Psikoloji Yazlları 2012, 15, 1-10.

105. Tanaka, J.S.; Panter, A.Y.; Winborne, W.C. Dimensions of the need for cognition: Subscales and gender differences. Multivar. Behav. Res. 1988, 23, 35-50. [CrossRef] 
106. Cenkseven, F.; Akar-Vural, R. Ergenlerin düşünme gereksinimine cinsiyetlerine göre problem çözme becerilerinin karşılaştırılması. Eurasian J. Educ. Res. 2006, 25, 45-53.

107. Demirci, S. Düşünme ihtiyacı ölçeği psikometrik özellikleri: Düşünme ihtiyacı, kontrol odağı inanc1 ve öğrenilmiş güçlülük ilişkilerinin incelenmesi. Master's Thesis, Hacettepe University, Ankara, Turkey, 1998.

108. Gülgöz, S. Need for cognition and cognitive performance from a cross-cultural perspective: Examples of academic success and solving anagrams. J. Psychol. 2001, 135, 100-112. [CrossRef]

109. Polat, R.H.; Tümkaya, S. Sınıf öğretmenliği öğrencilerinin düşünme ihtiyacına göre problem çözme becerilerinin incelenmesi. İlköğretim Online 2010, 9, 346-360.

110. Erözkan, A. Üniversite öğrencilerinin bağlanma stilleri ve karar stratejileri. Uluslararası Avrasya Sosyal Bilimler Dergisi 2011, 2, 60-74.

111. Leondari, A.; Kiosseoglou, G. The relationship of parental attachment and psychological separation to the psychological functioning of young adults. J. Soc. Psychol. 2000, 140, 451-466. [CrossRef] [PubMed]

112. Yılmaz, B. Üniversite Öğrencilerinin Kişilerarası İletişim Becerileri ve Bağlanma Stilleri Arasındaki İlişki. Master's Thesis, Muğla University, Muğla, Turkey, 2007.

113. Atkinson, R.L.; Atkinson, R.C.; Hilgard, E. Psikolojiye Giriş (Volume 1); Atakay, K.; Atakay, M.; Yavuz, A., Translators; Sosyal Yayınlar: İstanbul, Turkey, 1995.

114. Dökmen, Z.Y. Toplumsal cinsiyet, sosyal psikolojik açıklamalar; Remzi Kitapevi: İstanbul, Turkey, 2014.

115. Zhou, G.; Luo, S. Higher Education input, technological innovation, and economic growth in China. Sustainability 2018, 10, 2615. [CrossRef]

116. Grilo, I.; Thurik, R. Determinants of entrepreneurial engagement levels in Europe and the US. Ind. Corp. Chang. 2008, 17, 1113-1145. [CrossRef]

117. Korkmaz, O. Üniversite öğrencilerinin girişimcilik eğilimlerini belirlemeye yönelik bir araştırma (Bülent Ecevit Üniversitesi Örneği). Afyon Kocatepe Üniversitesi İktisadi ve İdari Bilimler Fakültesi Dergisi 2015, 14, 209-226.

(C) 2018 by the authors. Licensee MDPI, Basel, Switzerland. This article is an open access article distributed under the terms and conditions of the Creative Commons Attribution (CC BY) license (http:/ / creativecommons.org/licenses/by/4.0/). 